\title{
PELAKSANAAN AMDAL, UKL DAN UPL SERTA IPLC DI DKI JAKARTA
}

\author{
Oleh : \\ Nusa Idaman Said \\ Kelompok Teknologi Pengelolaan Air Bersih dan Limbah Cair, Pusat Pengkajian dan Penerapan Teknologi \\ Lingkungan, BPPT
}

\begin{abstract}
Pelaksanan tentang analisis mengenai dampak lingkungan secara nasional di atur berdasarkan Peraturan Pemerintah Nomor 27 Th 1999 tentang Analisis Mengenai Dampak Lingkungan Hidup (AMDAL). Sejak diberlakukannya Peraturan Pemerintan Nomor 27 tahun 1999 ini dan Undang-Undang Nomor 22 Tahun 1999 tentang Otonomi daerah, sebagian besar penilaian AMDAL dilaksanakan oleh Komisi Penilai Amdal Daerah, sedangkan kegiatan yang bersifat strategis, Lintas Negara dan Propinsi dinilai oieh Komisi Penilai Amdal Pusat (Meneg LH).

Dalam rangka pelaksanaan AMDAL di Propinsi DKI Jakarta, Gubernur telah mengeluarkan Keputusan Gubernur Provinsi DKI Jakarta No. 2863 tentang Jenis Rencana Usaha dan/atau Kegiatan Yang Wajib Dilengkapi Dengan AMDAL. Keputusan Gubernur Nomor 2863 Tahun 2001 tersebut mengatur 12 sektor atau bidang yang meliputi :Bidang pertahanan dan Keamanan; Bidang Pertanian; Bidang Perikanan; Bidang Kesehatan; Bidang Perhubungan Darat,Laut,Udara, teleko-munikasi; Bidang Perindustrian; Bidang Prasarana Wilayah; Bidang Energi dan Sumber Daya Mineral yaitu Pertambangan Umum/ Ketenaga Listrikan/Minyak dan Gas Bumi/Geologi Tata lingkungan; Bidang Pariwisata; Bidang Pengembangan Nuklir; Bidang Pengelolaan Limbah Bahan Berbahaya dan Beracun (B3); serta Bidang Rekayasa Genetika.

Makalah ini membahas masalah mekanisme pelakasanaan AMDAL, UKL, UPL serta ijin pembuangan limbah cair (IPLC) di Propinsi DKI Jakarta.
\end{abstract}

Kata Kunci : AMDAL, UKL, UPL, IPLC, DKI Jakarta.

\section{PENDAHULUAN}

Masalah pengelolaan lingkungan hidup di Indonesia telah diatur berdasarkan UndangUndang No.23 Tahun 1997 tentang Pengelolaan Lingkungan Hidup. Berdasarkan undang-undang tersebut sasaran pengelolaan lingkungan hidup adalah tercapainya keselarasan, keserasian, dan keseimbangan antara manusia dan lingkungan hidup; terwujudnya manusia Indonesia sebagai insan lingkungan hidup yang memiliki sikap dan tindak melindungi dan membina lingkungan hidup; terjaminnya kepentingan generasi masa kini dan generasi masa depan; tercapainya kelestarian fungsi lingkungan hidup; terkendalinya pemanfaatan sumber daya secara bijaksana; serta terlindungnya Negara Kesatuan Republik Indonesia terhadap dampak usaha dan/atau kegiatan di luar wilayah negara yang menyebabkan pencemaran dan/atau perusakan lingkungan hidup.

Undang Undang Nomor 23 tahun 1997 tentang Pongelolaan Lingkungan Hidup yang terdiri dari 10 Bab dan 52 pasal mengatur beberapa hal antara lain:

> Hak, kewajiban dan peran serta masyarakat dalam memperoleh lingkungan hidup yang baik dan sehat, menerima informasi dan berperan serta dalam pengelolaan lingkungan hidup, memelihara kelestarian, mencegah dan menanggulangi pencemaran, dan memberikan informasi yang benar dan akurat mengenai lingkungan hidup.

$>$ Wewenang pengelolaan lingkungan hidup yang dalam hal ini dilaksanakan secara terpadu oleh perangkat kelembagaan yang dikoordinasi oleh Menteri dengan mengikutsertakan peran pemerintah Daerah.

$>$ Pelestarian fungsi lingkungan hidup melalui pendataan Baku Mutu Lingkungan dan kriteria baku kerusakan lingkungan hidup.

$>$ Persyaratan penataan lingkungan hidup yang meliputi Rekomendasi Analisis Mengenai Dampak Lingkungan (AMDAL), pengawasan terhadap penataan lingkungan hidup, sanksi administrasi bagi pelanggar, audit lingkungan hidup.

$>$ Penyelesaian sengketa lingkungan hidup dapat ditempuh melalui pengadilan atau diluar pengadilan.

> Mengatur Sanksi dan Ketentuan Pidana yang secara skematis adalah sebagai berikut. 
Untuk menjamin pelestarian fungsi lingkungan hidup, maka setiap usaha dan/atau kegiatan dilarang melanggar baku mutu dan kriteria baku kerusakan lingkungan hidup. Ketentuan mengenai baku mutu lingkungan hidup, pencegahan dan penanggulangan pencemaran serta pemulihan daya tampungnya diatur dengan Peraturan Pemerintah. Sedangkan ketentuan mengenai kriteria baku kerusakan lingkungan hidup, pencegahan dan penanggulangan kerusakan serta pemulihan daya dukungnya diatur dengan Peraturan Pemerintah.

Setiap rencana usaha dan/atau kegiatan yang kemungkinan dapat menimbulkan dampak besar dan penting terhadap lingkungan hidup, wajib memiliki analisis mengenai dampak lingkungan hidup (AMDAL). Ketentuan tentang rencana usaha dan/atau kegiatan. yang menimbulkan dampak besar dan penting terhadap lingkungan hidup, sebagaimana dimaksud serta tata cara penyusunan dan penilaian analisis mengenai dampak lingkungan hidup ditetapkan dengan Peraturan Pemerintah.

Setiap penanggung jawab usaha dan/atau kegiatan wajib melakukan pengelolaan limbah hasil usaha dan/atau kegiatan. Penanggung jawab usaha dan/atau kegiatan sebagaimana dimaksud di atas dapat menyerahkan pengelolaan limbah tersebut kepada pihak lain. Untuk ketentuan pelaksanaannya diatur lebih lanjut dengan Peraturan Pemerintah.

\section{ANALISIS MENGENAI DAMPAK LINGKUNGAN (AMDAL)}

Analisis Mengenai Dampak Lingkungan Hidup (AMDAL) adalah kajian mengenai dampak besar dan penting suatu usaha dan / atau kegiatan yang direncanakan pada lingkungan hidup yang diperlukan bagi proses pengambilan keputusan tentang penyelenggaraan usaha dan / atau kegiatan dampak besar dan penting adalah perubahan lingkungan hidup yang sangat mendasar yang diakibatkan oleh suatu usaha dan / atau kegiatan, wajib menyusun AMDAL dan dinilai oleh Komisi Penting AMDAL. Pelaksanan tentang analisis mengenai dampak lingkungan secara nasional di atur berdasarkan Peraturan Pemerintah Nomor 27 Th 1999 tentang Analisis Mengenai Dampak Lingkungan Hidup (AMDAL).

Lingkup Dokumen AMDAL meliputi antara lain :

- Kerangka Acuan AMDAL (KA AMDAL) adalah ruang lingkup kajian analisis dampak lingkungan hidup yang merupakan hasil pelingkupan.
- AMDAL adalah telaahan secara cermat dan mendalam tentang dampak besar dan penting suatu rencana usaha dan / atau kegiatan.

- Rencana Pengelolaan Lingkungan Hidup (RKL) adalah upaya penanganan dampak besar dan penting terhadap lingkungan hidup yang ditimbulkan akibat dari rencana / usaha dan / atau kegiatan.

- Rencana Pemantauan Lingkungan hidup (RPL) adalah upaya pemantauan komponen lingkungan hidup yang terkena dampak besar dan penting akibat dari rencana / usaha dan / atau kegiatan.

- Amdal merupakan bagian dari perijinan yang dilaksanakan sebelum kegiatan dimulai atau bagian dari perencanaan.

- Bagi rencana kegiatan diluar kegiatan yang berdampak besar dan penting, wajib menyusun dokumen Upaya Pengelolaan Lingkungan (UKL) dan Upaya Pemantauan Lingkunqan (UPL).

Sejak diberlakukannya Peraturan Pemerintan Nomor 27 tahun 1999 ini dan Undang-Undang Nomor 22 Tahun 1999 tentang Otonomi daerah, sebagian besar penilaian AMDAL dilaksanakan oleh Komisi Penilai Amdal Daerah, sedangkan kegiatan yang bersifat strategis, Lintas Negara dan Propinsi dinilai oieh Komisi Penilai Amdal Pusat (Meneg LH).

\section{PELAKSANAAN AMDAL, UKL DAN UPL DI DKIJAKARTA}

Jenis dan besarnya kegiatan yang wajib menyusun AMDAL adalah kegiatan yang diperkirakan menimbulkan dampak besar dan penting yang disesuaikan dengan daya dukung dan daya tampung lingkungan. Dalam rangka pelaksanaan AMDAL di Propinsi DKI Jakarta, Gubernur telah mengeluarkan Keputusan Gubernur Provinsi DKI Jakarta No. 2863 tentang Jenis Rencana Usaha dan/atau Kegiatan Yang Wajib Dilengkapi Dengan AMDAL.

Keputusan Gubernur Nomor 2863 Tahun 2001 tersebut mengatur 12 sektor atau bidang yang meliputi :

- Bidang pertahanan dan Keamanan.

- Bidang Pertanian.

- Bidang Perikanan.

- Bidang Kesehatan.

- Bidang Perhubungan Darat,Laut,Udara, teleko-munikasi.

- Bidang Perindustrian.

- Bidang Prasarana Wilayah. 
- Bidang Energi dan Sumber Daya Mineral yaitu. Pertambangan Umum/ Ketenaga Listrikan / Minyak dan Gas Bumi / Geologi Tata lingkungan.

- Bidang Pariwisata.

- Bidang Pengembangan Nuklir.

- Bidang Pengelolaan limbah Bahan berbahaya dan racun (B3).

- Bidang Rekayasa Genetika.

Amdal, UKL dan UPL merupakan bagian perizinan daerah yang disusun bersamaan dengan studi kelayakan rencana usaha/kegiatan, sehingga layak secara teknis, ekonomi dan lingkungan. Pembinaan pelaksanaan Amdal dan UKL/UPL diselenggarakan oleh Badan Pengelolaan Lingkungan Hidup Daerah yang dalam pelaksanaannya berkoordinasi dengan instansi yang berwewenang, Walikotamadya setempat, dan unsur Kabupaten Administrasi Kepulauan Seribu.

Upaya Pengelolaan Lingkungan (UKL) Serta Upaya Pemantauan Lingkungan (UPL) dalam perizinan daerah diatur berdasarkan Keputusan Gubernur Provinsi DKI Jakarta No. 99 Tahun 2002 tentang pelaksanaan analisis mengenai dampak lingkungan hidup (AMDAL) dan upaya pengelolaan lingkungan (UKL) serta upaya Pemantauan lingkungan (UPL) dalam perijzinan daerah.

Informasi jenis dan besaran kegiatan wajib AMDAL dan UKL/UPL sudah harus diinformasikan instansi yang berwenang sejak pengurusan ijin yang paling awal seperti ijin prinsip. AMDAL dan UKL/UPL disusun bersamaan dengan pengurusan ijin pembebasan lahan, surat ijin penunjukan penggunaan tanah (SIPPT), Blok Plan dan lain-lain. IMB hanya dapat diterbitkan setelah rekomendasi AMDAL atau persetujuan UKL/UPL diperoleh. ljin penggunaan bangunan (IPB) dapat diberikan apabila AMDAL dan UKL/UPL dilaksanakan. Dan laporan implementasi RKL/RPL dan UKL/UPL disampaikan secara periodik ke instansi pembina BPLHD Propinsi/Wilayah dan Walikotamadya/Kabupaten Administrasi.

\subsection{AMDAL di Dalam Proses Perijinan Daerah}

AMDAL mencakup dokumen Kerangka Acuan, dokumen Analisis Dampak Lingkungan, dokumen Rencana Pengelolaan Lingkungan dan Rencana Pemantauan Linkungan. Apabila penanggung jawab rencana dan/atau kegiatan yang berdasarkan penggolongannya wajib menyusun AMDAL, maka aparat yang bertugas di bidang perijinan wajib menjelaskan kedudukan dokumen dokumen AMDAL di dalam mekanisme perijinan di Propinsi DKI jakarta.

Berdasarkan kajian yang dilakukan oleh instansi terkait, maka keterkaitan AMDAL di dalam mekanisme perijinan dijelaskan sebagai berikut :

a. Apabila rencana usaha dan/atau kegiatan diwajibkan mengurus ijin pembebasan lahan dan ijin penunjukan penggunaan tanah, maka pra proposal dan/atau proposal yang menjadi kelengkapan permohonan, pemrakarsa wajib mencantumkan bukti proses penyusunan AMDAL.

b. Pada saat penyampaian permohonan ijin penunjukan penggunaan tanah, aparat yang bertugas wajib memberitahukan bahwa rencana usaha dan/atau kegiatan yang ijinnya dimohon tergolong wajib AMDAL. Selanjutnya, penanggung jawab rencana usaha dan/atau kegiatan segera menyusun kerangka acuan AMDAL dan untuk keperluan tersebut, penanggung jawab rencana usaha dan/atau kegiatan menghubungi konsultan bidang AMDAL.

c. Berita acara pembahasan kerangka acuan AMDAL dapat digunakan sebagai rekomendasi dalam pengurusan Ketepatan Rencana Kota (KRK), SIPPT, ljin Membangun Prasarana (IMP) dan atau penerbitan ljin Pendahuluan mendirikan Bangunan (IP-MB).

d. ljin Mendirikan bangunan (IMB) akan diterbitkan oleh instansi yang berwenang apabila Komisi Penilai AMDAL daerah telah menerbitkan rekomendasi AMDAL untuk rencana usaha dan/atau kegiatan.

e. Ijin Penggunaan Bangunan (IPB) dan ljin Usaha Tetap (IUT) akan diterbitkan oleh instansi yang berwenang apabila RKL atau UPL telah dilaksanakan sesuai dengan ketentuan yang berlaku dan dilaporkan kepada instansi yang bertanggung jawab dan instansi yang berwenang.

\subsection{UKL dan UPL di Dalam Proses Perijinan Daerah}

Penanggung jawab rencana usaha dan/atau kegiatan yang berdasarkan penggolongannya wajib menysusn UKL Atau UPL, maka aparat yang bertugas di bidang perijinan wajib menjelaskan kedudukan dokumen UKL/UPL dalam mekanisme perijinan di Propinsi DKI Jakarta. 
Berdasarkan kajian yang dilakukan oleh instansi terkait, mengacu pada peraturan perundang-undangan yang berlaku di Propinsi DKI jakarta, maka kegiatan UKL/UPL dalam mekanisme perijinan dijelaskan sebagai berikut :

a. ljin Mendirikan bangunan (IMB) akan diterbitkan oleh instansi berwenang apabila pemrakarsa usaha atau kegiatan telah melengkapai dokumen UKL/UPL.

b. ljin Penggunaan bangunan (IPB) diterbitkan oleh instansi yang berwenang apabila pemrakarsa usaha atau kegiatan telah melaporkan pelaksanaan UKL/UPL kepada instansi yang bertanggung jawab di tingkat walikotamadya/Kabupaten Administatif dan tingkat Propinsi.

\subsection{AMDAL, UKL dan UPL di Dalam Proses Kemitraan Pembangunan Fisik}

Pada umumnya, lingkup kegiatan pembangunan fisik yang dilaksanakan melalui proses kemitraan adalah pembangunan prasarana dan atau sarana kota. Lingkup kegiatan kemitraan dapat berwujud "Built Operation Transfer (BOT) maupun Built Transfer Operation (BTO)", ataupun wujud lain melalui kemitraan antara PEMDA dengan pihak swasta yang memperjelas lembaga yang bertanggung jawab melakukan pengelolaan lingkungan akibat suatu kegiatan pembangunan.

Dalam rangka mengoptimalkan tujuan dan kegunaan sarana dan atau prasarana lingkungan yang dibangun, perlu diidentifikasi sejak dini dampak lingkungan yang tidak tergolong besar dan penting atau secara teknologi dampak pentingnya dapat dikelola. Identifikasi dimaksud dilakukan melalui pelaksanaan studi AMDAL yang mencakup penyusunan kerangka acuan, penyusunan studi AMDAL, dan penyusunan rencana pengelolaan lingkungan (RKL) dan rencana pemantauan lingkungan serta upaya pengelolaan lingkungan (UKL) dan upaya pemantauan lingkungan (UPL).

Jenis rencana kegiatan dan atau usaha yang wajib melakukan AMDAL diatur melalui Keputusan Gubernur DKI Jakarta Nomor 2863 tahun 2001 yang mengatur tentang jenis rencana usaha dan/atau kegiatan yang wajib dilengkapi dengan analisis mengenai dampak lingkungan. Sedangkan untuk jenis rencana kegiatan usaha dan/atau kegiatan di DKI Jakarta yang wajib dilengkapi dengan UKL/UPL diatur melalui Surat Keputusan Gubernur DKI Jakarta Nomor 189 tahun 2002.

\section{MEKANISME PELAKSANAAN AMDAL, UKL dan UPL}

Mekanisme Pelaksanaan Amdal dan UKL/UPL dalam Proses Perizinan dapat dilihat pada Gambar 1.

Jenis dan besarnya rencana kegiatan yang wajib menyusun dokumen Upaya Pengelolaan Lingkungan (UKL) dan Upaya Pemantauan Lingkungan (UPL) adalah rencana usaha dan/atau kegiatan yang tidak menimbulkan dampak besar dan penting,atau secara teknologi dampak pentingnya dapat dikelola. Mekanisme pembahasannya berada di luar mekanisme AMDAL. Dalam pembahasannya, setidak-tidaknya melibatkan Intansi pembina teknis dan Unsur wilayah Kota/Kabupaten

Usaha/Kegiatan yang Wajib Dilengkapi dengan Upaya Pengelolaan Linglungan (UKL) serta Upaya Pemantauan Lingkungan (UPL) diatur berdasarkan Surat Keputusan Gubernur Provinsi DKI Jakarta No. 189 Tahun 2002.

Keputusan Gubernur no. 189/2002 ini terdiri dari 10 sektor/bidang meliputi : a. Bidang Perhubungan dan Telekomunikasi, b. Bidang Prasarana Wilayah, c. Bidang Pariwisata, d. Bidang Energi dan Sumber Daya Mineral, e. Bidang Pertanian, f. Bidang Peternakan, g. Bidang Perikanan, h. Bidang Kehutanan, I. BidangPerindustrian,dan j. Bidang Perdagangan. Sesuai Keputusan Meneg LH No. 86/2002, Pembinaan penilaian UKL/UPL ini dilaksanakan oleh instansi yang bertanggungjawabdalam pengelolaan lingkungan hidup.

\subsection{Keterlibatan Masyarakat dan Keterbukaan Informasi Dalam Proses Analisis Dampak Lingkungan}

Keputusan Gubernur Provinsi DKI Jakarta No. 76 Tahun 2001 tentang: Pedoman Keterlibatan Masyarakat dan Keterbukaan Informasi Dalam Proses Analisis Dampak Lingkungan.

Melibatkan Dewan Kota/Kabupaten, Dewan Kelurahan (Dekel) serta peran pemerhati lingkungan seperti WALHI dan Organisasi Lingkungan lainnya dalam proses AMDAL.

Sebelum penyusunan KA AMDAL, terlebih dahulu dilakukan pengumuman rencana kegiatan dan rencana penyusunan AMDAL melalui papan pengumuman di lokasi proyek selama 30 hari dan melalui media cetak 


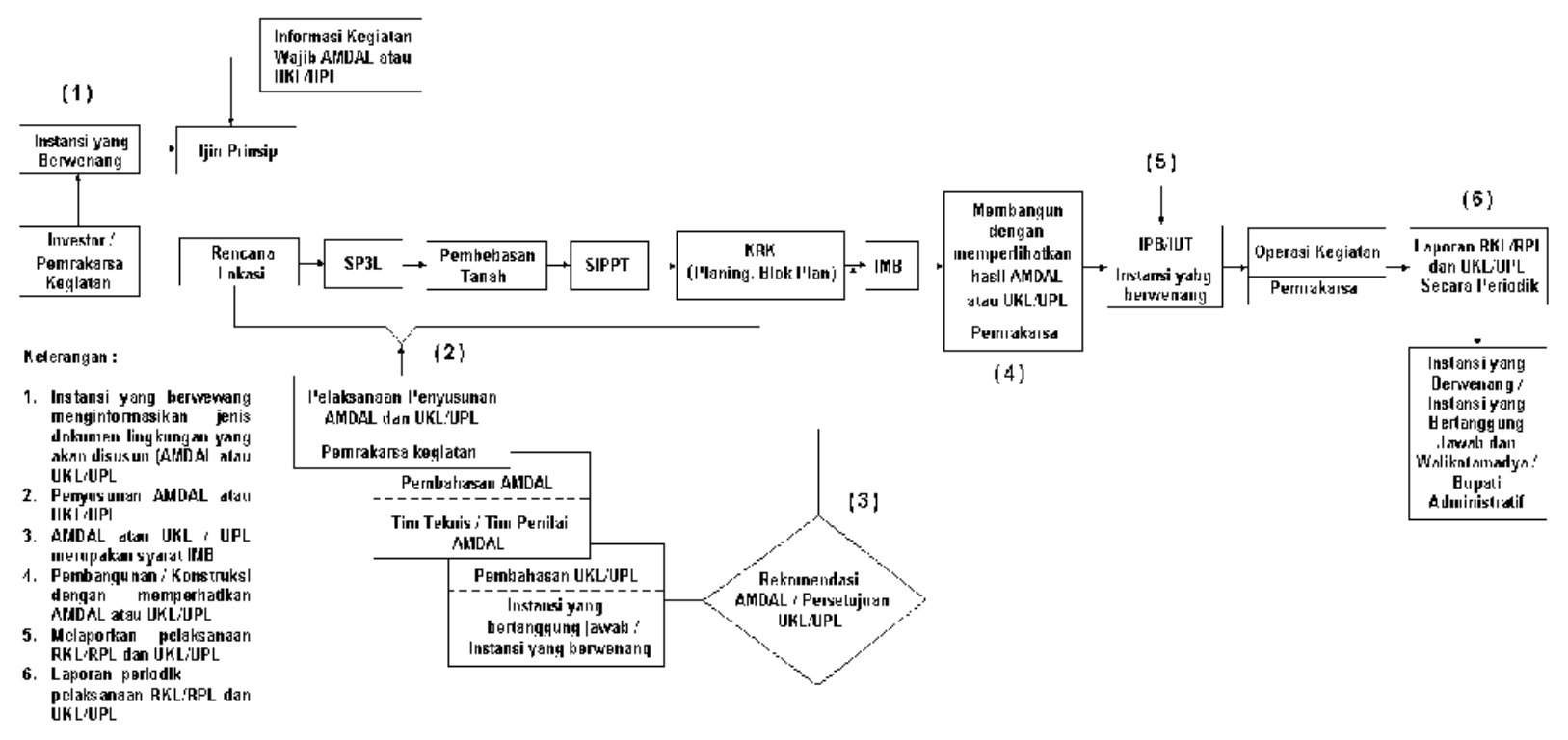

Gambar 12.1 : Mekanisme Pelaksanaan AMDAL dan UKL/UPL Dalam Proses Perijinan.

Sumber : BPLHD Propinsi DKI Jakarta.

\section{IJIN PEMBUANGAN LIMBAH CAIR (IPLC) DI DKI JAKARTA}

\subsection{Dasar Hukum}

Air merupakan sumber daya alam untuk memenuhi hajat orang banyak sehingga perlu dilestarikan kemampuannya agar tetap bermanfaat bagi kehidupan manusia serta mahluk hidup lainnya. Dan dalam rangka itulah perlu kiranya dilakukan pengendalian beban limbah yang masuk ke perairan/badan air melalui perizinan membuang limbah cair. Ijin pembuangan limbah cair di DKI Jakarta diatur berdasarkan Keputusan Gubernur Provinsi DKI Jakarta melalui Surat Keputuasan Gubernur DKI Jakarta Nomor 30 Tahun 1999, tentang: Pembuangan Limbah Cair. Melalui ljin Pembuangan Limbah Cair (IPLC) dapat dipantau tentang kepatuhan pemenuhan baku mutu limbah cair, beban limbah, kualitas dan kuantitas limbah cair.

\subsection{Tujuan IPLC}

Berdasarkan Surat Keputuasan Gubernur DKI Jakarta Nomor 30 Tahun 1999, pasal 2, tujuan IPLC adalah :

- Maksud : sebagai upaya pembatasan beban limbah cair yang dibuang ke badan air atau perairan umum serta sumber air.
- Tujuan IPLC adalah mengurangi beban pencemaran agar badan air atau sumber air tidak tercemar dan dapat digunakan untuk memenuhi berbagai kebutuhan sesuai dengan peruntukannya.

\subsection{Kegiatan Yang Wajib Memiliki IPLC}

Berdasarkan Surat Keputuasan Gubernur DKI Jakarta Nomor 30 Tahun 1999, pasal 3, kegiatan yang wajib mempunyai IPLC adalah :

1) Setiap orang atau badan hukum yang dalam operasinya akan dan atau telah membuang limbah cair ke perairan umum.

2) Setiap rencana kegiatan baru sebelum diberikan Undang Undang Gangguan (UUG) atau ljin Pemakaian Bangunan (IPB).

3) Bagi rencana kegiatan yang dilengkapi AMDAL dan berdasarkan studinya harus lebih ketat dari ketentuan baku mutu limbah cair (BMLC) maka pembatasan limbahnya didasarkan pada hasil studi AMDAL tersebut.

\subsection{Tata Cara Memeperoleh IPLC}

\section{A. Persyaratan}

Berdasarkan Surat Keputuasan Gubernur DKI Jakarta Nomor 30 Tahun 1999, pasal 5, beberapa persyaratan untuk memperoleh IPLC adalah : 
- Mengajukan permohonan secara tertulis kepada Gubernur Kepala Daerah melalui BLPHD.

- Permohonan izin pembuangan limbah cair haruslah dilengkapi dengan :

a) Data isian tentang pembuangan limbah cair;

b) Peta lokasi pembuangan limbah cair dan pengambilan air yang berskala proporsional;

c) Foto copy akte pendirian perusahaan;

d) Foto copy IMB dan IPB;

e) Fotocopy Undang-Undang Gangguan;

f) Desain unit pengolah limbah dan cara kerjanya;

g) Memiliki dokumen RKL dan RPL atau dokumen UKL dan UPL;

h) Hasil pemeriksaan limbah cair dari laboratorium BPLHD DKI Jakarta

i) Serta surat pernyataan kesanggupan untuk mentaati persyaratan yang berlaku.

Mekanisme penerbitan ljin Pebuangan Limbah cair (IPLC) dapat dilihat seperti pada Gambar 2.

\section{B. Debit Maksimum}

Debit maksimum yang disetujui berdasarkan pada produksi riil selama 3 (tiga) tahun terakhir dibandingkan dengan kapasitas produksi sesuai ijin dan kapasitas produksi terpasang (SK Gub No.30/1999, Pasal 7 ayat 2).

\subsection{Tim Evaluasi IPLC}

Tim Evaluasi IPLC adalah Tim yang dibentuk dengan keputusan gubernur melalui Kepala BPLHD Propinsi DKI Jakarta yang mempunyai tugas antara lain :

1) Meneliti kelengkapan teknis permohonan IPLC.

2) Memberikan rekomendasi teknis kelayakan upaya penurunan beban limbah dan kelayakan pembuangan limbah cair. (SK Gub No.30/1999, Pasal 8).

Tim evalusai terdiri dari beberapa instansi dan pakar lingkungan antara lain :

a. Instansi Pembina (Dinas Pekerjaan Umum, Dinas Pariwisata, Dinas Kesehatan, Dinas Perindustrian dan Perdaganagan, Dinas Perumahan). b. BPLHD Propinsi DKI Jakarta (Bidang Perencanaan Dampak Lingkungan, Bidang Pengendalian Pencemaran, Bidang Pengendalian Kerusakan, Laboratorium Lingkungan).

c. Pakar Lingkungan (BPPT, Universitas Indonesia, Universitas TRISAKTI dll).

(SK Gub No.30/1999, Pasal 6).

IPLC dapat diberikan kepada kegiatan yang telah beroperasi maupun kegiatan baru setelah mendapatkan rekomendasi teknis kelayakan upaya penurunan beban limbah dan kelayakan pembuangan limbah cari dari Tim Evaluasi. (SK Gub No.30/1999, Pasal 8).

\subsection{Masa Berlaku IPLC}

IPLC berlaku untuk 5 (lima) tahun dan setelah itu dapat diperpanjang lagi. (SK Gub No.30/1999, Pasal 7 ayat 3).

IPLC tidak berlaku apabila dicabut atau tidak diperpanjang lagi. (SK Gub No.30/1999, Pasal 9 ayat 1$)$.

\subsection{Pencabutan IPLC}

Berdasarkan Surat Keputuasan Gubernur DKI Jakarta Nomor 30 Tahun 1999, Pasal 9, ijin pembuangan limbah cair (IPLC) dari suatu kegiatan dapat dicabut apabila :

1) Tidak melakukan kegiatan usaha selama jangka waktu tiga tahun berturut-turut sejak IPLC dikeluarkan.

2) Melakukan pelanggaran sesuai dengan kesepakatan dalam Surat Keputusan IPLC.

3) Menyebabkan terjadinya kerusakan lingkungan hidup atau pencemaran akibat pembuangan limbah cair.

\subsection{Tata Cara Pencabutan IPLC}

Pencabutan IPLC yang telah dikeluarkan dapat dilakukan dengan dua cara yakni pencabutan dengan peringatan dan pencabutan tanpa peringatan.

Pencabutan IPLC dengan peringatan dilakukan dengan beberapa cara :

a) Proses peringatan tertulis.

b) Penutupan sementara saluran pembuangan limbah cair untuk jangka waktu 30 hari. 
MEKANISME PENERBITAN IJIN PEMBUANGAN LIMBAH CAIR (IPLC)

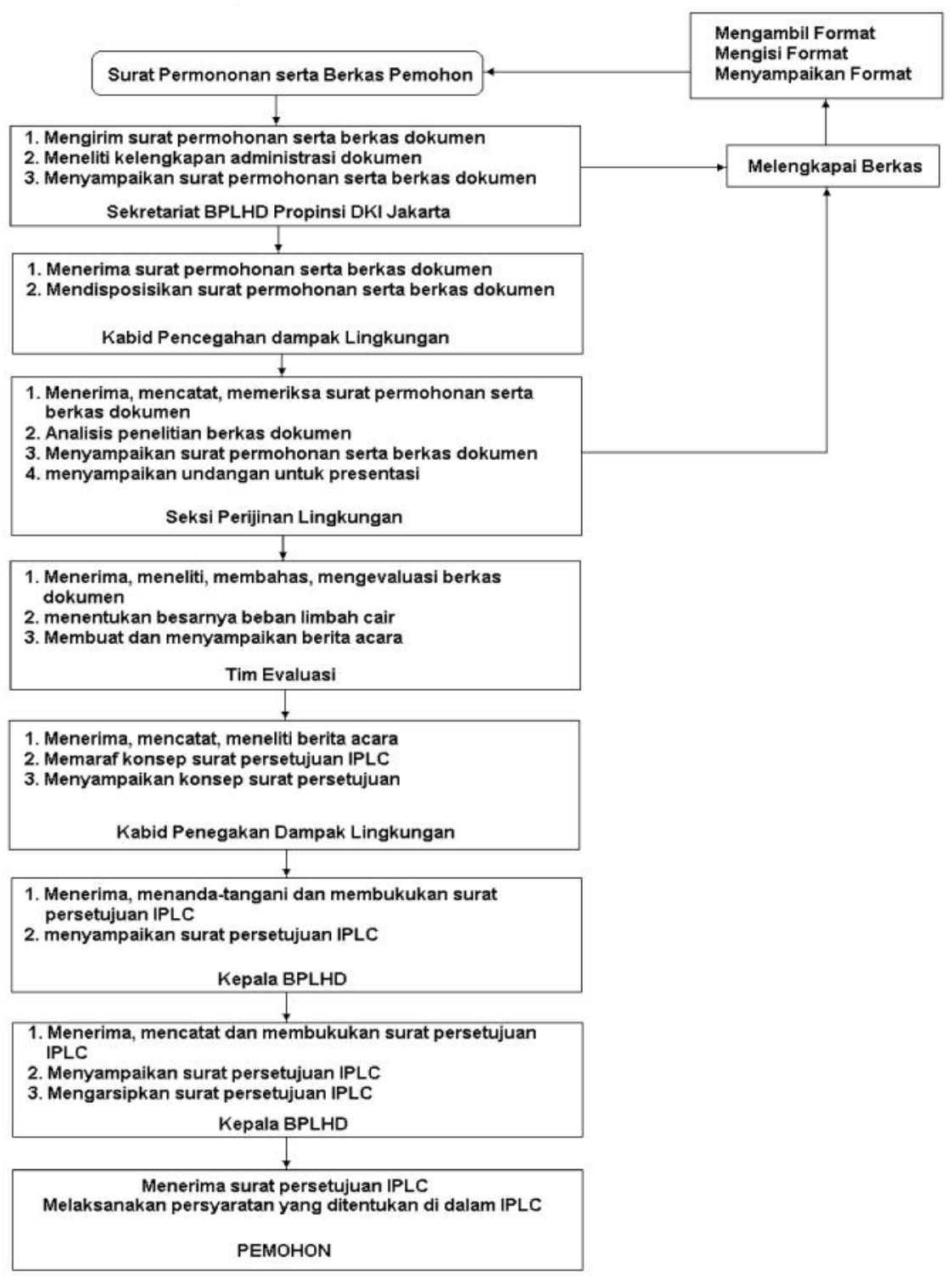

Catatan :

Proses penerbitan IPLC 15 hari kerja terhitung sejak kelengkapan persyaratan teknis terpenuhi.

Gambar 2 : Mekanisme penerbitan ljin Pebuangan Limbah cair (IPLC) di DKI Jakarta.

c) Pencabutan IPLC.

Pencabutan IPLC tanpa peringatan dilakukan apabila:

1) Tidak melakukan kegiatan usaha selama tiga tahun berturut-turut sejak IPLC diterbitkan.

2) Melakukan kegiatan yang menyebabkan terjadinya kerusakan lingkungan hidup atau pencemaran.

(SK Gub No. 30/1999, Pasal 10)

\subsection{Kewajiban Pemegang IPLC}

Berdasarkan Surat Keputuasan Gubernur DKI Jakarta Nomor 30 Tahun 1999, Pasal 11, setiap kegiatan usaha atau badan hukum yang telah memeperoleh IPLC mempunyai beberapa kewajiban yang harus dipenuhi antara lain :

1) Mentaati baku mutu limbah cair (BMLC) yang telah ditetapkan.

2) Tidak melampaui beban maksimum yang telah ditentukan di dalam IPLC. 
3) Tidak melakukan pengenceran.

4) Memisahkan saluran pembuangan air limbah proses dan air limbah domestik, kecuali jika diolah secara bersama.

5) Memasang alat ukur debit limbah cair yang dibuang.

6) Membangun bangunan dan saluran pembuangan limbah cair untuk memudahkan pengambilan sampel air limbah.

7) Memeriksakan air limbah secara berkala setiap tiga bulan.

8) Melakukan swapantau selama pembuangan air limbah dan melaporkan hasilnya secara berkala ke BPLHD setiap tiga bulan.

\subsection{Perpanjangan IPLC}

Setelah lima tahun IPLC dapat diperpanjang dengan cara :

1) Membuat surat permohonan secara tertulis kepada Gubernur Kepala Daerah melalui BPLHD Propinsi DKI Jakarta dengan melampirkan formulir permohonan dan IPLC sebelumnya.

2) Dilakukan verifikasi lapangan oleh Tim BPLHD.

3) Jika debit yang dihasilkan tidak sesuai dengan debit maksimum yang tertera di dalam IPLC sebelumnya (khususnya jika melebihi debit maksimum) maka harus mengajukan permohonan baru.

4) Jika terjadi perluasan kegiatan usaha (kapasitas kegiatan sudah tidak sesuai dengan IPLC sebelumnya) maka harus mengajukan permohonan baru.

Perpanjangan IPLC diberikan setelah mendapatkan hasil rekomendasi kelayakan teknis pembuangan limbah cair dari Tim Evaluasi dan hasil analisa laboratoriun terhadap air limbah yang akan dibuang telah memenuhi baku mutu limbah cair (BMLC) yang telah ditetapkan.

\subsection{Pembinaan Dan Pengawasan}

Pembinaan dan pengawasan IPLC secara teknis dilaksanakan oleh BPLHD Propinsi dibantu oleh BPLHD Wilayah serta berkoordinasi dengan instansi pembina. Untuk pengawasan dan peninjauan lapangan oleh tim pengawas dapat dilakukan sewaktu-waktu. Kegiatan pemantauan meliputi beberapa hal yaitu :

a. Pemeriksaan air limbah secara berkala atau sewaktu-waktu.

b. Pengecekan tingkat ketaatan terhadap baku mutu limbah cair yang tercantum di dalam IPLC.

c. Pengamatan terhadap upaya yang telah dilakukan.

d. Evaluasi terhadap hasil pemantauan, pengecekan dan pengamatan yang dapat ditindak lanjuti dengan penegakan hukum atau penghargaan.

(SK Gub No. 57/2003 Pasal 7)

Mekanisme penerbitan, evaluasi dan pematauan ljin Pembuangan Limbah Cair (IPLC) di DKI Jakarta secara sederhana dapat diterangkan seperti pada Gambar 3. Dalam rangka memberikan motivasi bagi kegiatan usaha untuk mengelola limbah cairnya dengan baik maka Pemerintah Daerah Khusus Ibukota Jakarta memberikan piagam penghargaan. Bagi kegiatan yang memperoleh piagam penghargaan miminal satu tahun sebelumnya akan diberikan insentif dan kemudahan secara khusus dalam proses penerbitan IPLC.

\section{PENETAPAN PERUNTUKAN BAKU MUTU AIR SUNGAI ATAU BADAN AIR SERTA BAKU MUTU LIMBAH CAIR}

Dengan meningkatnya perkembangan Industri, dan Pembangunan yang cukup tinggi di Wilayah DKI Jakarta akan meningkatkan volume limbah cair yang dihasilkan, sehingga akan semakin bertambah pula pencemaran pada perairan atau badan air.

Dalam rangka menjaga terpeliharanya kualitas air Sungai/Badan Air serta Limbah Cair maka ditetapkanlah Surat Keputusan Gubernur Provinsi DKI Jakarta No. 582 Tahun 1995, tentang penetapan peruntukan Baku Mutu Air Sungai atau Badan Air Serta Baku Mutu Limbah Cair.

Surat Keputusan Gubernur tersebut mengatur batasan-batasan kualitas air Sungai/Badan Air serta Limbah Cair di wilayah DKI Jakarta. 


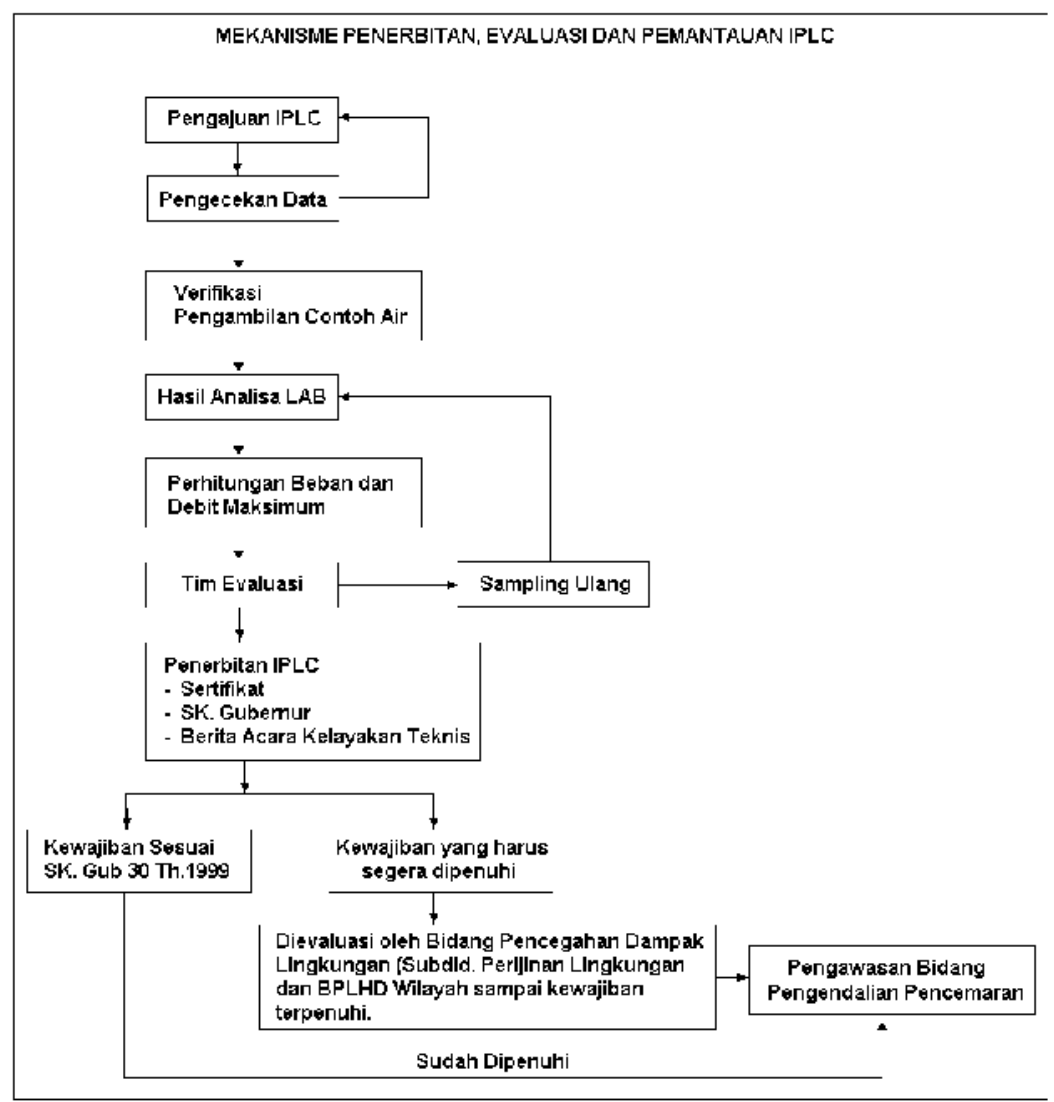

Gambar 3 : Mekanisme penerbitan, evaluasi dan pematauan ljin Pebuangan Limbah cair (IPLC) di DKI Jakarta.

A. Baku Mutu Air Sungai/Badan Air adalah: Batas atau kadar mahluk hidup, zat energi atau komponen lain yang ada atau harus ada dan atau unsur pencemar yang ditenggang adanya dalam air pada sumber air tertentu sesuai dengan peruntukannya.

B. Baku Mutu Air Limbah Cair adalah: Batas kadar dan jumlah unsur pencemar yang ditenggang adanya dalam limbah cair untuk dibuang dari satu jenis kegiatan tertentu.

\section{SURAT PERNYATAAN \\ PENGELOLAAN LINGKUNGAN (SPPL)}

Surat Keputusan Gubernur No. 2333 tahun 2002 tentang Jenis Usaha/Kegiatan yang Wajib Dilengkapi dengan Surat Pernyataan Pengelolaan Lingkungan (SPPL) di Provinsi DKI Jakarta

1. Proses pelaksanaan usaha/kegiatan yang wajib dilengkapi dengan Surat Pernyataan Pengelolaan Lingkungan (SPPL) dilaksanakan oleh : Instansi
Pembina Teknis di Tingkat Walikotamadya atau Kabupaten Administrasi dibawah koordinasi Walikotamadya atau Bupati Administrasi

2. Surat Pernyataan Pengelolaan Lingkungan (SPPL) dibuat oleh Pemrakarsa Kegiatan dengan dibubuhi materai dan diketahui oleh Instansi Pembina

Teknis di tingkat Walikotamadya atau Kabupaten Administrasi

Jenis usaha/kegiatan yang wajib dilengkapi dengan Surat Pernyataan Pengelolaan Lingkungan (SPPL) :

- Bidang Perhubungan

- Bidang Prasarana Wilayah

- Bidang Pariwisata

- Bidang Kesehatan

- Bidang Energi dan Sumber Daya Mineral

- Bidang Pertanian

- Bidang Peternakan

- Bidang Perikanan

- Bidang Kehutanan

- Bidang Perindustrian dan Perdagangan 


\section{DAFTAR PUSTAKA}

- Keputusan Gubernur Kepala Daerah Khusus lbukota Jakarta Nomor 582 Tahun 1995 Tentang Penetapan Peruntukan Dan Baku Mutu Air Sungai atau Badan Air Serta Baku Limbah Cair Di Wilayah Daerah Khusus lbukota Jakarta

- Keputusan Gubernur Propinsi DKI Jakarta No. 2863 tentang Jenis Rencana Usaha dan/atau Kegiatan Yang Wajib Dilengkapi Dengan AMDAL.

- Keputusan Gubernur Propinsi DKI Jakarta Nomor 30/1999 tentang ljin Pembuangan Limbah cair (IPLC).

- Keputusan Gubernur Propinsi DKI Jakarta Nomor 57 Tahun 2003 tentang Petunjuk Pelaksanaan Izin Pembuangan Limbah Cair di Propinsi Daerah Khusus Ibukota Jakarta.

- Keputusan Gubernur Propinsi DKI Jakarta Nomor 57/2003 tentang Petunjuk Pelaksanaan Izin Pembuangan Limbah
Cair di Propinsi Daerah Khusus Ibukota Jakarta.

- Keputusan Menteri Negara Lingkungan Hidup Republik Indonesia Nomor : Kep52/Menlh/10/1995 Tentang Baku Mutu Limbah Cair Bagi Kegiatan Hotel.

- Peraturan Gubernur Propinsi DKI Jakarta Nomor 122 Tahun 2005 Tentang Pengelolaan Air Limbah Domestik Di Provinsi DKI Jakarta.

- Peraturan Gubernur Provinsi Daerah Khusus Ibukota Jakarta Nomor 68 Tahun 2005 Tentang Perubahan Keputusan Gubernur Provinsi Daerah Khusus Ibukota Jakarta Nomor 115 Tahun 2001 Tentang Pembuatan Sumur Resapan

- Peraturan Pemerintah Republik Indonesia Nomor 82 Tahun 2001 Tentang Pengelolaan Kualitas Air Dan Pengendalian Pencemaran Air.

- Undang-Undang Republik Indonesia Nomor 23 Tahun 1997 Tentang Pengelolaan Lingkungan Hidup. 
Tabel : Daftar Regulasi Tentang Lingkungan Hidup

\section{UNDANG-UNDANG}

$1 \quad$ Undang-Undang Republik Indonesia Nomor 23 Tahun 1997

2 Undang-Undang Republik Indonesia Nomor 17 Tahun 2004
Pengelolaan Lingkungan Hidup

Perubahan Iklim Bumi Akibat Peningkatan Konsentrasi Gas Rumah Kaca di Atmosfer

\section{AIR}

1 Peraturan Pemerintah Republik Indonesia Nomor 20 Tahun 1990

2 Peraturan Pemerintah Republik Indonesia Nomor 82 Tahun 2001

3 Keputusan Gubernur Propinsi DKI Jakarta Nomor 582/1995

4 Keputusan Gubernur Propinsi DKI Jakarta Nomor 299/1996

5 Keputusan Gubernur Propinsi DKI Jakarta Nomor 30/1999

6 Keputusan Gubernur Propinsi DKI Jakarta Nomor 57/2003

$7 \quad$ Keputusan Menteri Negara Lingkungan Hidup Nomor 111 Tahun 2003

8 Keputusan Menteri Negara Lingkungan Hidup Nomor 112 Tahun 2003

9 Keputusan Menteri Negara Lingkungan Hidup Nomor 115 Tahun 2003

10 Keputusan Menteri Negara Lingkungan Hidup Nomor 142 Tahun 2003

11 Keputusan Gubernur Propinsi DKI Jakarta Nomor 1893/1991

12 Keputusan Gubernur Propinsi DKI Jakarta Nomor 123/1995

13 Keputusan Gubernur Propinsi DKI Jakarta Nomor 57/2003

14 Keputusan Gubernur Propinsi DKI Jakarta Nomor 115/2001

15 Keputusan Menteri Negara Lingkungan Hidup Nomor 35A Tahun 1995

\section{Pengendalian Pencemaran Air}

Pengelolaan Kualitas Air dan Pengendalian Pencemaran Air

Baku Mutu Air Sungai dan Limbah Cair di DKI

Petunjuk Pelaksanaan Penetapan

Peruntukan dan Baku Mutu Air Sungai/Badan

Air Serta Baku Mutu Limbah Cair di Wilayah DKI Jakarta

Ijin Pembuangan Limbah cair (IPLC)

Petunjuk Pelaksanaan Izin Pembuangan Limbah Cair di Propinsi Daerah Khusus Ibukota Jakarta

Pedoman Mengenai Syarat dan Tata Cara

Perijinan serta Pedoman Kajian Pembuangan

Air Limbah ke Air atau Sumber Air

Baku Mutu Air Limbah Domestik

Pedoman Penentuan Status Mutu Air

Perubahan atas Kep. MENLH No. 111 tahun 2003

Tindakan Administratif Bagi

Perusahaan/Kegiatan/Industri Yang

Menimbulkan Perusakan dan Pencemaran Lingkungan

Petunjuk Pelaksanaan Tindakan Administratif Bagi Perusahaan/Industri/Kegiatan Peserta Prokasih

Petunjuk Pelaksanaan IPLC di Propinsi DKI Jakarta

Pembuatan Sumur Resapan di Propinsi DKI Jakarta

Proper Prokasih 


\section{LIMBAH B3}

1 Peraturan Pemerintah Republik Indonesia Nomor 19 Tahun 1999

2 Peraturan Pemerintah Republik Indonesia Nomor 12 Tahun 1995

3 Peraturan Pemerintah Republik Indonesia Nomor 18 Tahun 1999

4 Peraturan Pemerintah Republik Indonesia Nomor 85 Tahun 1999

5 SE Bapedal 08 / SE / 02 / 97

6 Keputusan Kepala BAPEDAL Nomor KEP-02/BAPEDAL/09/1995

7 Keputusan Kepala BAPEDAL Nomor KEP-05/BAPEDAL/09/1995

8 Keputusan Kepala BAPEDAL Nomor KEP-01/BAPEDAL/1995

9 Keputusan Kepala BAPEDAL Nomor KEP-03/BAPEDAL/1995

10 Keputusan Kepala BAPEDAL Nomor KEP-04/BAPEDAL/1995

11 Keputusan Kepala BAPEDAL Nomor KEP-68/BAPEDAL/1994

12 Keputusan Kepala BAPEDAL Nomor KEP-255/BAPEDAL/1995
Pengelolaan Limbah B3

Perubahaan PP No. 19/1994

Pengelolaan Limbah B3

Perubahan PP No. 18 / 1999

Minyak Pelumas Bekas

Dokumen Limbah B3

Simbol dan Label Limbah B3

Tata Cara dan Persyaratan Teknis,

Penyimpanan dan Pengumpulan Limbah B3

Persyaratan Teknis Pengelolaan Limbah B3

Tata Cara Persyaratan Penimbunan,

Persyaratan Lokasi Bekas Penimbunan Limbah B3

Tata Cara Memperoleh Izin Penyimpanan, Pengumpulan, Pengoperasian Alat Pengelolaan, Pengolahan dan Penimbunan Akhir Limbah B3

Penyimpanan dan Pengumpulan Minyak Pelumas Bekas

\section{UDARA}

1 Peraturan Pemerintah Republik Indonesia Nomor 41 Tahun 1999

2 Keputusan Presiden Republik Indonesia Nomor 23/1992

3 Keputusan Menteri Negara Lingkungan Hidup Nomor KEP15/MENLH/4/1999

4 Keputusan Menteri Negara Lingkungan Hidup Nomor KEP16/MENLH/4/1996

5 Keputusan Menteri Negara Lingkungan Hidup Nomor KEP35/MENLH/10/1993

6 Keputusan Menteri Negara Lingkungan Hidup Nomor KEP13/MENLH/3/1995

7 Keputusan Menteri Negara Lingkungan Hidup Nomor KEP45/MENLH/10/1997

8 Keputusan Menteri Negara Lingkungan Hidup Nomor KEP48/MENLH/11/1996

9 Keputusan Menteri Negara tentang Pengendalian Pencemaran Udara.

tentang Pengesahan Vienna Convetion dan Montreal Protocol

tentang Program Langit Biru.

tentang Penetapan Prioritas Propinsi Daerah Tingkat I Program Langit Biru.

tentang Ambang Batas Emisi Gas Buang Kendaraan Bermotor.

tentang Baku Mutu Emisi Sumber Tidak Bergerak.

tentang Indeks Standar Pencemar Udara.

tentang Baku Tingkat Kebisingan.

tentang Baku Tingkat Getaran. 
Lingkungan Hidup Nomor KEP-

49/MENLH/11/1996

10 Keputusan Menteri Negara Lingkungan Hidup Nomor KEP50/MENLH/11/1996

11 Keputusan Menteri Negara Lingkungan Hidup Nomor 141 Tahun 2003

12 Keputusan Menteri Negara Lingkungan Hidup Nomor 42/MENLH/11/1994

13 Keputusan Menteri Negara Lingkungan Hidup Nomor 30/MENLH/2001

14 Keputusan Menteri Perindustrian dan Perdagangan No. 110/MPP/Kep/1/1998

15 Keputusan Menteri Perindustrian dan Perdagangan No. 790/MPP/Kep/12/2002

16 Keputusan Kepala BAPEDAL Nomor KEP-205/BAPEDAL/07/1996

17 Keputusan Kepala BAPEDAL Nomor KEP-107/BAPEDAL/11/1997

18 Peraturan Daerah Provinsi DKI Jakarta Nomor 2 Tahun 2005

19 Surat Keputusan Gubernur KDKI Jakarta Nomor 2359/1987

20 Keputusan Gubernur Propinsi DKI Jakarta Nomor 551/2001

21 Keputusan Gubernur Propinsi DKI Jakarta Nomor 670/2000

22 Keputusan Gubernur Propinsi DKI Jakarta Nomor 95 Tahun 2000

23 Keputusan Gubernur Propinsi DKI Jakarta Nomor 1041 Tahun 2000

24 Peraturan Gubernur Provinsi DKI Jakarta Nomor 75 Tahun 2005

25 Keputusan Kepala Badan Pengelolaan Lingkungan Hidup Daerah Provinsi DKI Jakarta Nomor 59/2006

26 Keputusan Kepala Badan Pengelolaan Lingkungan Hidup Daerah Provinsi DKI Jakarta Nomor 68/2006 tentang Baku Tingkat Kebauan.

tentang Ambang Batas Emisi Gas Buang

Kendaraan Bermotor Tipe Baru dan Kendaraan Yang Sedang Diproduksi tentang Pedoman Umum Pelaksanaan Audit Lingkungan Organisasi

tentang Pedoman Pelaksanaan Audit Lingkungan Hidup yang Diwajibkan

tentang Larangan Memproduksi dan Memperdagangkan Bahan Perusak Lapisan Ozon serta Memproduksi dan Memperdagangkan Barang Baru yang Menggunakan Bahan Perusak Lapisan Ozon (Ozone Depleting Substances) tentang Perubahan KEPMENINDAG RI No. 110/MPP/Kep/1/1998

tentang Pedoman Teknis Pengendalian Pencemaran Udara Sumber Tidak Bergerak. tentang Pedoman Teknis Perhitungan dan Pelaporan serta Informasi Indeks Standar Pencemar Udara.

tentang Pengendalian Pencemaran Udara.

tentang Penanaman Pohon Langka

tentang Penetapan Baku Mutu Udara Ambien dan Baku Tingkat Kebisingan di Propinsi DKI Jakarta.

tentang Penetapan Baku Mutu Emisi Sumber Tidak Bergerak di Propinsi DKI Jakarta.

tentang Pemeriksaan Emisi dan Perawatan Mobil Penumpang Pribadi di Propinsi DKI Jakarta.

tentang Baku Mutu Udara Emisi Kendaraan Bermotor di Propinsi DKI Jakarta.

tentang Kawasan Dilarang Merokok

tentang Pedoman Umum Pengendalian

Kualitas Udara Dalam Ruangan (KUDR)

tentang Petunjuk Teknis Kawasan Dilarang Merokok 


\begin{tabular}{|c|c|c|}
\hline & AMDAL & \\
\hline 1 & $\begin{array}{l}\text { Peraturan Pemerintah Republik } \\
\text { Indonesia Nomor } 27 \text { Tahun } 1999\end{array}$ & Analisa Mengenai Dampak Lingkungan \\
\hline 2 & $\begin{array}{l}\text { Keputusan Menteri Negara } \\
\text { Lingkungan Hidup Nomor } \\
\text { 39/MENLH/8/1996 }\end{array}$ & $\begin{array}{l}\text { Jenis Usaha / Kegiatan yang Wajib } \\
\text { Dilengkapi dengan Analisis Mengenai } \\
\text { Dampak Lingkungan }\end{array}$ \\
\hline 3 & $\begin{array}{l}\text { Keputusan Menteri Negara } \\
\text { Lingkungan Hidup Nomor } 17 \text { Tahun } \\
2001\end{array}$ & Jenis usaha wajib AMDAL \\
\hline 4 & $\begin{array}{l}\text { SE MENLH No. B. } \\
\text { 1234/MENLH/08/1999 }\end{array}$ & Kegiatan wajib UKL / UPL \\
\hline 5 & $\begin{array}{l}\text { Keputusan Menteri Negara } \\
\text { Lingkungan Hidup Nomor } 12 \text { Tahun } \\
1999\end{array}$ & Pedoman UKL / UPL \\
\hline 6 & Kep. Gub KDKI Jakarta No. 189/2002 & $\begin{array}{l}\text { Jenis Usaha/Kegiatan yang Wajib Dilengkapi } \\
\text { Dengan Upaya Pengelolaan Lingkungan } \\
\text { (UKL) dan Upaya Pemantauan Lingkungan } \\
\text { (UPL) di Propinsi DKI Jakarta }\end{array}$ \\
\hline 7 & $\begin{array}{l}\text { Keputusan Menteri Negara } \\
\text { Lingkungan Hidup Nomor } 3 \text { Tahun } \\
2000\end{array}$ & $\begin{array}{l}\text { Jenis Usaha / Kegiatan yang Wajib } \\
\text { Dilengkapi dengan Analisis Mengenai } \\
\text { Dampak Lingkungan }\end{array}$ \\
\hline 8 & $\begin{array}{l}\text { Keputusan Menteri Negara } \\
\text { Lingkungan Hidup Nomor } 45 \text { Tahun } \\
2005\end{array}$ & $\begin{array}{l}\text { Pedoman Penyusunan Laporan } \\
\text { Pelaksanaan RKL/RPL }\end{array}$ \\
\hline 9 & $\begin{array}{l}\text { Keputusan Gubernur Propinsi DKI } \\
\text { Jakarta Nomor 2863/2001 }\end{array}$ & $\begin{array}{l}\text { Jenis Rencana Usaha/Kegiatan yang Wajib } \\
\text { Dilengkapi Dengan AMDAL }\end{array}$ \\
\hline 10 & $\begin{array}{l}\text { Keputusan Gubernur Propinsi DKI } \\
\text { Jakarta Nomor 99/2002 }\end{array}$ & $\begin{array}{l}\text { Mekanisme Pelaksanaan AMDAL dan UKL } \\
\text { serta UPL dalam Perizinan Daerah }\end{array}$ \\
\hline 11 & $\begin{array}{l}\text { Keputusan Gubernur Propinsi DKI } \\
\text { Jakarta Nomor 2333/2002 }\end{array}$ & $\begin{array}{l}\text { Jenis Usaha / Kegiatan yang Wajib } \\
\text { Dilengkapi dengan SPPL di Propinsi DKI } \\
\text { Jakarta }\end{array}$ \\
\hline 12 & $\begin{array}{l}\text { Keputusan Gubernur Propinsi DKI } \\
\text { Jakarta Nomor } 76 \text { Tahun } 2001\end{array}$ & $\begin{array}{l}\text { Pedoman Operasional Keterlibatan } \\
\text { Masyarakat dan Keterlibatan Informasi } \\
\text { Dalam AMDAL }\end{array}$ \\
\hline
\end{tabular}

